\title{
Multicultural Education in Slovakia: Perspectives and Risks
}

\author{
Peter Kondrla \\ Constantine the Philosopher University in Nitra, \\ 1 Hodzova St., Nitra, 949 74, Slovak Republic \\ $\square$ pkondrla@ukf.sk
}

\begin{abstract}
The article analyses 20 years of experience with multicultural education in Slovakia. The starting point is to examine the causes and reasons why multicultural education has been included in the education system. The rationale for the introduction of multicultural education is interpreted in the context of the current possibilities and needs of society, identifying mainly the problems that multicultural education solves today. The basic principles and pillars of multicultural education are introduced and at the same time their strengths and weaknesses are examined. Emphasis is placed on human dignity and social responsibility as sources on which other values of multicultural education are based. In contrast to these principles is the environment in which education takes place. The school and family environment do not offer a sufficient principled background, do not prefer and often do not respect the values of multiculturalism. The resulting conflict of principles and environment poses the biggest problem and risk in multicultural education. Specific attention is paid to the issue of education in the mother tongue, this problem in Slovakia mainly affects the Roma minority. The inability to learn in one's mother tongue is contrary to equal opportunities as well as to the possibilities for the development of the human person in the context of his or her dignity. Finding perspectives requires a change from above, in the setting of the school environment as well as a change from below, i.e. a change in the value orientations and personal attitudes of individual teachers and changes in their preparation for the future profession.
\end{abstract}

Key words: multicultural education, multiculturalism, tolerance, Slovakia, mother tongue, minority, cultural diversity

\section{Introduction}

Multicultural education is included in the content of education with regard to the Slovak cultural environment, where members of different ethnic, national, religious and cultural origins have lived together for centuries. ${ }^{1}$ At the same time,

(C) Kondrla P., 2021

(c) (i) This work is licensed under a Creative Commons Attribution 4.0 International License

https://creativecommons.org/licenses/by/4.0/

${ }^{1}$ Slovak State Pedagogical Institute. (2010). Multicultural education. (In Slovak.) Retrieved July 21, 2021, from https://www.statpedu.sk/sk/svp/statny-vzdelavaci-program/svp-prvystupen-zs/prierezove-temy/multikulturna-vychova/ 
traditional cultural diversity is currently exacerbated by a number of trends, which are often covered by the concept of globalization. One of these trends, which significantly increases the diversity of cultures in Slovakia, is the migration of members of more distant and hitherto unknown cultures and subcultures. However, the multiculturalism of Slovak society has never meant not only the peaceful coexistence of various groups of the population, but it has always been and still is marked by prejudices and stereotypes, which manifest themselves in various forms of intolerance, racism or xenophobia (Mistrík, 2011).

Pupils of all ages will increasingly be exposed to different cultural influences in their personal and public lives and will increasingly come into contact with members of other cultures. Therefore, they need to be prepared for these challenges and able to recognize, respect and promote the different cultural anchorages in their environment. The aim of the cross-cutting theme of multicultural education is therefore educational and training activities aimed at developing knowledge of various traditional and new cultures and subcultures, accepting cultural diversity as a social reality and developing tolerance, respect and prosocial behaviour and action in relation to cultural diversity (Bartkova, 2015). Educational activities are aimed at making the school and school education function as equitable systems, where all students have the same opportunity to develop their potential. Pupils get to know their culture and other cultures, history, customs and traditions of their representatives, respect these cultures as equal and are able to communicate and cooperate constructively with their members.

Multicultural education can naturally be integrated into the humanities and social sciences. However, elements of multicultural education can be developed in the content and methodological level or with the help of suitable examples in science subjects or in the teaching of mother tongue and foreign languages.

\section{Cultural differences - the cause of problems}

Cultural difference is a relative term. The perception of cultural differences is not independent of the culture in which we speak of differences. It is not uncommon for one and the same act or gesture to be understood differently in different cultures. There are cultures where a smile is a sign of good mood and openness to communication, but in other cultures this gesture may have the opposite meaning (Abbar, Shaheed, 2021). Similarly, from the cultural context, direct eye contact can be understood as an act of good behavior and in another culture as an expression of audacity and indecency. A very good example in this sense is also eating, where cultural expressions and customs very often differ, which can leave us with conflicting feelings. From such a primary experience, we can then easily form a prejudice about the uncivilized culture of the barbarians. It is these prejudices that create space for intolerant behavior. Often the problem is the lack of knowledge and lack of information about other cultures or ethnicities (Halah, 2016). We encounter other cultures and their manifestations more and more frequently, so it is necessary to know and understand what their behavior stems from.

As a rule, an individual grows up in a limited environment, which includes the family, the immediate surroundings, the city, or the state in which we identify with the nation. We adapt our behavior and habits to the environment in which we grow up. It is natural for us to have a certain rhythm of life, certain cycles in be- 
havior, specific patterns that we consider natural. We adapt to the influence of the environment and on the basis of this adaptation we consider our behavior as their behavior of our immediate surroundings to be the standard. Confrontation with other patterns of behavior that are typical of other cultures creates uncertainty, anxiety and fear in us (Bogdanova, 2016). This fear is based on confrontation with another. Otherness represents something unknown to a person and therefore perceives others as risky or even dangerous.

On the other hand, we are confronted with a globalized world, a globalized society that offers us some kind of universal value that we can use wherever we find ourselves in the world. Although this assumption of world citizenship seems optimistic, it only applies in a specific environment. Large urban agglomerations have their own value system in which cultural, national or ethnic differences are lost, but outside these agglomerations there are countries that retain their cultural specificities and their unique original view of the world, which they do not want to give up. Cultural differences are the cause of many disputes and conflicts, which arise precisely because of a misunderstanding of customs, way of life, different values and so. At present, the migration process takes place not only at the level of large cities and conurbations, but also at the level of small towns or even villages. And it is precisely in the space outside the globalized agglomerations that a real clash of cultures and civilizations is taking place.

\section{Stereotype and prejudice}

Behind the clash of cultures as the cause is usually a stereotype or prejudice (Belinskaya, 2018). It is these two elements that education for tolerance and multiculturalism must focus on. We consider the stereotype to be a monotonous, stable pattern of behavior, which we apply automatically in our actions. Frequent manifestations of stereotyping of others are discrimination and prejudice, i.e. different behavior towards some people only because they belong to a certain group (religious, ethnic, national, social). Some authors understand stereotype and prejudice as synonymous, others define prejudice as a negative type of stereotypical behavior (Tkáčová, Al-Absiová, Al-Absi, Pavlíková, 2021). In our opinion, the stereotype can also have a positive meaning when, for example, we say that the French are elegant or people with glasses are intelligent. In general, we can say that the stereotype arises from the simplification, hyperbolization, generalization and understanding of some cultural attributes as natural. For example, the Roma are said to have wandering and irresponsibility in their blood and will never want to work (Kyuchukov, New, 2018).

The real risk arises when we attribute negative qualities to people in advance, without any experience, without knowing them. In this case, we are talking about prejudice, i.e. a negative stereotype, in which a negative evaluation or condemnation is contained, and such prejudice is the basis of a negative relationship with another person or group (Tkáčová, Pavlíková, Tvrdoň, Prokopyev, 2021).

Today, when we have a large amount of information at our disposal, we are prone to quickly settling and drawing conclusions, not often to hastily categorizing and judging the people we meet. We often follow information from the media, acquaintances or the Internet, and this information is not verified and often not even authorized (Mosanya, Kwiatkowska, 2021). This is information that is often strong- 
ly emotionally subdued and therefore leaves a deep mark on us. All the more so if this information includes fear, fear of the unknown, stranger or unknown. In terms of creating stereotypes, we generalize this information and apply it to entire groups of people. Then we consider every Roma a thief, every Italian a noisy and so on. These attitudes are not dominated by rational judgment based on real experience, dominated by prejudice, which is based only on negative emotions instead of facts.

Prejudices based on negative emotions cause social exclusion and consequent discrimination. Social exclusion and discrimination can be characterized as a process in which individuals and entire groups of people are deprived of access to the resources necessary to participate in the social, economic and political activities of society as a whole. The process of social exclusion is primarily the result of poverty, low income. However, other factors also contribute to it, such as discrimination against low education or poor living conditions. People who are socially excluded are cut off from institutions, services, social networks and educational opportunities (Kroupova, 2008).

The relationship between the majority society and minorities is often based on the exclusion of and discrimination against the minority. Part of this discrimination is the problem of communication in the circle, which should be the subject of multicultural education. Communication, as we know, is a specific type of interaction between two people in which we pass on certain information. Communication can be of a different nature. It can be an order, information, warning, praise, humiliation and so. And it is prejudice that can have a significant effect on how we communicate.

Our meeting with a member of another ethnic group based on the prejudice that he or she is a person who makes a living from theft, does not fulfill his or her duties and lives at the expense of others will be marked by this prejudice. Our attitudes always make the person feel that we do not trust him, because I will constantly check my bag and wallet, we will not believe what he says or what he promises. Thanks to such communication, we actually educate ourselves in such a way that we convince a member of this ethnic group that they did not cause them to social contact and that they do not belong to society. In this way, it leads me to start behaving according to our prejudices. Several experiences from schools show that students from other ethnic groups who tried to prove that they are hardworking were still negatively evaluated and their efforts were appreciated. ${ }^{2}$ Based on this experience, many of these students resigned and stopped trying. They adapted their behavior to what the majority society thought of them, and they began to behave according to its imagination. We can therefore say that society itself is responsible for the position of the minority. In such an environment, it is very difficult to have a positive effect through multicultural education.

\section{Goals of multicultural education}

The aim of multicultural education is to eliminate the individual prejudices that the majority society has and at the same time break free from the vicious circle of negative influence on minorities (Banks, 2001a). The multicultural approach is realized in the school by fulfilling two basic and complementary principles:

${ }^{2}$ Council of Europe Publishing. (2004). The religious dimension of intercultural education: Conference proceedings, Oslo, Norway, 6-8 June 2004. Strasbourg. 


\section{1) principle of inclusion;}

2) principle of teaching focused on the learner.

The inclusive approach creates an environment in the classroom where children are not seen as commonplace, as objects of everyday practice, on the contrary, the child is perceived as a unique person, regardless of whether he comes from the majority or minority, whether he is a child with a disability or exceptionally gifted child (Grant, Sleeter, 2006). If we want the teacher to support the individual development of the student and his abilities, then it is essential that he knows the student's needs and understands how the student thinks and why he thinks in this way. For this deeper knowledge, it is necessary to have information about the family background of the student, whether there will be negative experiences in his environment and so. Thanks to this knowledge, it is then possible to plan a teaching process for a specific student, a process that will allow students personal development. In the field of multicultural education, unlike other subjects, we can modify the educational program and adapt it to the needs of students (Banks, 2001b; Hašková et al., 2020).

Multicultural education is most effective when the principles of multiculturalism are manifested throughout school life (Králik, Máhrik, 2019a). These are mainly the following principles:

- respecting the diversity of students and teachers, teaching and educational styles, ways of communication, dressing, etc. Individual approach to students, creating conditions for individual ways of learning, support for the weaker and not creating elite groups. Assessment that respects the individual peculiarities of students and teachers. Respect for individuals and support for the formation of selfesteem of students and teachers, assistance in revealing strengths, highlighting the contribution to common tasks or highlighting originality, providing opportunities for the manifestation of individual peculiarities. Respect for different cultural traditions and creating space for their presentation. Mutual trust and openness in communication (Kyselova, Ligas, 2017);

- cooperation between students, classes, teachers, systematic development of cooperation and building opportunities for independent formation of creative or work teams. Creating common goals that everyone can take part in fulfilling (Ambrozy et al., 2021). Delegation of powers in the group and in solving tasks, mutual support in risky tasks, not condemning a person by mistake, but finding ways to remedy. The application of individual principles is adjusted according to the organizational and operational capabilities of the school. They are applied in all areas of school life in the organization and daily operation, in relationships between teachers and students, in formal and informal curricula and in extracurricular activities (Karatsova, Isaev, 2016).

In this way, multicultural education can contribute to preparing people for encounters with different cultures. The skills and experience that students acquire in multicultural education allow them to communicate peacefully and objectively, not to use unnecessary emotions in communication and thus contribute to creating a peaceful and creative environment in which it is possible not only to resolve conflicts effectively but also cooperate creatively (Faltyn, 2005). Thanks to multicultural education, students are able to effectively eliminate the risk of potential conflicts between members of different cultures and at the same time are able to 
eliminate existing conflicts. In general, their behavior creates an atmosphere that reduces the risk of creating tension and new conflicts.

The creators of the educational program realistically approach the possibilities of multicultural education (Pavlikova et al., 2021). Therefore, they point out that even the widespread introduction of multicultural education into school teaching is not a guarantee, because no further conflicts between members of other cultures will arise in the future. Likewise, multicultural education cannot be seen as a magical tool to remove inequality and inequality between people and social groups from society (Gorski, 2009). Nor can we assume that, thanks to multicultural education, we would create a community of love and cooperation, an ideal, utopian society.

Multicultural education is based on several basic pillars, which complement each other and it is not possible to omit any of them. The first basic pillar, on which stands not only multicultural education but also the whole pedagogy and the whole educational effort, is the value of the human person. At the beginning, there is an understanding of the dignity of the human person, regardless of their gender, nationality, state, ethnic, cultural or other affiliation (Binetti et al., 2019). Acceptance of the unquestionability and inalienability of dignity in each individual is a necessary starting point for the development of other competencies and skills. Part of accepting human dignity is also respecting his individual needs. It means that we cannot force another person to profess the same values, to want what we like, and to act as we do. As important as accepting the dignity of the individual is accepting the value of the social group and society. Man alone is unable to achieve his goals without social cooperation and the help of others. Thanks to multicultural education, he can understand that members of other ethnic cultures or religions can also help to achieve his own goals and that creating tension between groups in society leads to problems and complications that make it difficult for the individual to self-realize and achieve his goals (Zalec, Pavlikova, 2019).

Understanding the importance of the existence of the legal system and equality of people before the law is also an important pillar of multicultural education. According to the first pillar, which speaks of the dignity of the human person, it also applies here that every person is a person who has equal rights and obligations arising from the legal system. Customs and traditions sometimes rise above legal norms, refer to the fact that this has always been the case, and try to weaken the meaning and significance of legal norms in this way. Therefore, emphasizing the importance of the legal system and equality before the law is key and necessary for multicultural education. A very important pillar also seems to be the development of critical thinking, which is currently very underdeveloped, we dare say that it is in crisis (Kralik, Mahrik, 2019b). The development of critical thinking is not only a matter of multicultural education, but falls within the competence of all subjects in the school (Khukhlaev et al., 2020). Simply put, as part of the educational process, it is essential to lead students to critically monitor their surroundings so that they do not automatically receive all information from any source. On the contrary, students need to acquire skills in verifying resources and working with information (Siskova, 2008). It is precisely misinformation that creates unnecessary tension and misunderstanding between members of different cultures of nations or ethnic groups. In addition to critical thinking, 
it is very important to develop practical experiences, i.e. experiences with other nations, cultures, with the thinking of other ethnic groups. The more experience pupils gain, the more likely they are to understand another culture, to understand its value system and, most importantly, to understand that other cultures do not pose a real threat or risk to be feared (Petrovič, Murgaš, 2020).

\section{Problems of multicultural education}

Multicultural education is offered in schools as the so-called cross-sectional object. This means that it is tied to teaching in other subjects of the curriculum. The analysis of the educational program for primary schools showed that a minimum of space is devoted to multicultural education. The curriculum refers to the fact that individual issues and problems of multicultural education will be integrated into other subjects, but it is not precisely defined how and into which (Kalustyants, 2011). Experience from practice in primary schools suggests that the issue of cross-cutting subjects, such as environmental education, civic education and so, receives minimal attention and emphasis on so-called main subjects, such as languages, mathematics or natural sciences (Tkáčová, Pavlíková, Tvrdoň, Jenisová, 2021).

The first problematic point is that multicultural teachers have only a very general document at their disposal, which is formulated in the level of recommendations and does not offer specific ways in which it would be possible to teach specific lessons. Multicultural education emphasizes the importance of the school environment, the climate in the classroom, but the role of the teacher remains a priority. At the same time, it is the teacher who can create and support a positive climate in the classroom or in the school corridors (Sandorova, 2011).

The second problematic point pointed out by the results of our analysis is the choice of topics for multicultural education. As we have already mentioned, these topics are either defined very generally or, on the contrary, they focus on local cultural groups, on local issues that are not enough to cover the whole complex of multiculturalism. The choice of topics is directed more towards negative issues such as racism, xenophobia and others. Little space is devoted to neutral and positive topics such as solidarity, cooperation, respect, uniqueness, uniqueness and the like. As we have already mentioned, he has a lot of space to choose and choose his own topic (Mistrík et al., 2008). However, experience shows us that this separate choice of topic does not always bring the expected effect and some teachers do not have a feeling for multicultural topics or are even themselves promoters or advocates of various forms of discrimination.

The third problematic point in multicultural education, according to our findings, is the problem of locality. Multicultural education in Slovakia tends to follow local problems, local ethnic groups (specifically Roma) and does not reflect multiculturalism as part of a global problem (Banks, 2001b). The principle of multicultural education should be to follow the plurality of cultures in a global, global context, which is closely related to environmental education. Just as we admire the quality of the environment of people around the world through our behavior, so we create a global cultural climate through our attitudes and behavior, we determine who another person is and what that person means to us. 
The way students think and make decisions, the way they approach problem solving, proves to be a fundamental problem. These learned patterns of behavior, in other words stereotypes, predominate in their decision-making process not only in relation to other cultures or ethnicities, but also in solving everyday problems (Kondrla, Tvrdoň, Tkáčová, 2020). In 2020, we conducted research to look at the ways young people use to solve their life problems. Research has shown that their decisions are largely influenced by emotional factors and information that does not come from credible sources (Durkova, 2020). More than the facts, emotional satisfaction or saturation of emotional need was important for the respondents. In other words, if the respondent wanted to experience fear, he focused on the information that mediates fear. Thus, for example, migrants could become synonymous with fear, but from a rational point of view they did not pose a real threat. The way the report was presented gave the impression of immediate life.

At the same time, our research has shown that in the decision-making process of the young generation, critical thinking is absent or used, it is used only in $20 \%$ of solved problems. In other cases, young people turn to other sources of information to help them make decisions. It is obvious that in such an environment it is very easy to spread the ideas of hatred, fear and to build an environment in which discrimination is present (Pavlíková, Žalec, 2019).

The quality of family education also proved to be a problem. The attitudes that students take and the arguments they use in many cases come from communication in the family or in peer groups (Banks, 2013). Teaching in schools seems to be in many cases in opposition to family education. The social and cultural values that are presented in school teaching and that children should adopt are rejected and unaccepted in family education. In family education, children are often led to attitudes of exclusivity, rejection of other opinions, disrespect for the demands and needs of classmates, false appeals to their own freedom without responsibility. From family upbringing come students who do not feel responsible for others, are not interested in the fate of others, live in a false individualism, where they require respect and help from each side, but at the same time refuse to help anyone else.

\section{Conclusion}

Multicultural education has long been part of the education system in European countries. Especially the countries of Western Europe, where a large number of migrants came and are coming. Experience from countries such as Switzerland, Finland, Norway or the Netherlands shows that language is the biggest problem for migrants. At first glance, it would seem that Slovakia and the countries of Central Europe in general are not affected by this problem. But the opposite is true. Minorities, specifically the Roma minority, often have difficulty communicating in the official language, and rarely Roma are unable to adequately express the content of what they want to communicate (Kondrla, Tkáčová, Tvrdoň, 2020). Experience from other European countries shows that the first and basic step for multicultural education is to accept language specificity. Unfortunately, this problem is overlooked, suggesting that multicultural education is not taken seriously.

The fundamental mistake of multicultural education, in the countries of Central Europe, is the inability to accept otherness and an other than equal partner (Tkáčová, Tvrdoň, Králik, Kalugina, 2021). As we have said, the principle of mul- 
ticultural acceptance is not the transformation of another into the same, but the cooperation with another as it is. The prevailing attitude, which has also been shown in our research, is the attitude of uniformity (Slavin et al., 2001). This means that if someone wants to live among us, he must be the same as we are, he must behave like us, his behavior must be understandable to us and he must respect all the rules that we have set and we respect. The same goes for the language he uses. Since the other must be the same as us, logically he must also use the same language as we use. This conservative attitude is once again being preferred by some political parties. Unfortunately, the political agenda adds to conservative reserved attitudes, which create imbalances in society and cause many misunderstandings.

We can say that our assumption about the inadequacy of the current concept of multicultural education has been confirmed. Multicultural education, as defined in the curricula for primary and secondary schools, does not reflect the real problems facing society and does not prepare students for conflict resolution or prevention (Garmon, 2004). Multicultural education as a whole is set up so that there must be someone who is right and someone who submits to being those who are domestic and those who come and adapt. Romani students are educated in the state language, regardless of whether they speak the language or not. It is obvious that they will not be able to progress in education in the same way as other students for whom the state language is also their mother tongue. National minorities such as Hungarians, Ukrainians, Germans or Bulgarians have such schools and opportunities.

In this situation, it is questionable whether it makes any sense to talk about multicultural education, when in the very principle of the school it is not ensured that the pupil can be educated so that he can get understandable knowledge (Tkáčová, Tvrdoň, Roubalova, Vasbieva, 2021). As mentioned above, pupils are automatically divided into those who are educating and learning in their mother tongue and those who need to adapt. This inequality, which begins in primary education, is then reflected in other educational opportunities, and new obstacles are constantly emerging that prevent minority children from developing their education, their personalities and their careers (Ukpokodu, 2003). We stated that the basis of multicultural education is also a real experience with a multicultural environment in practice, at school. However, the situation that pupils encounter at school is not a situation where a tolerant cultural environment really works, on the contrary, they encounter an environment where segregation, exclusion and inequality of opportunity work. In such an environment and in such conditions, it would be naive to expect that multicultural education will have any effect (Žalec, Pavlíková, 2019).

The solution to this situation is offered by multicultural education itself and the pillars on which it stands. As we have seen, the basic starting point is respect for the other person as well as respect for the social group, including their rights and equality before the law. If the education system were based on this premise, then it would consider education in a minority language to be a primary right that is not discussed. In the political and public debate, we are of the opinion that there is not enough funding for minority language education, that it requires special training for teachers who are not enough and are not willing to teach in the minority language (Gorski, 2006). On the one hand, therefore, we claim that everyone 
has the right to education, but at the same time we deny minorities the education of their mother tongue. We are moving in a vicious circle, the conditions of education are set in such a way that they produce social exclusion and reduce the possibility of access to education and later to employment.

This basic problem is beyond the reach of educational institutions, it is a systemic problem that has only a political solution. Of course, there is also the possibility of community social work, unfortunately we are talking about marginalized social groups, where the reality of such an intervention is problematic or impossible. A partial solution seems to be the comprehensive training of future teachers and educators who will be prepared to overcome obstacles and remove barriers that cause segregation and exclusion. Teachers from practice point out that in the schools where they work, they are reluctant to change anything, they have to adapt to the established regime of school operation and have no room to bring innovations or possible changes. If the teacher also manages to create an inclusive environment in his classroom, at a time when students are confronted with an open school environment, there are misunderstandings and conflicts (Gay, 2000). We remain confident that by gradually preparing new and new generations of teachers, we will also increase students' sensitivity to the topic of the dignity of the other person and their right to self-determination and self-realization.

\section{References}

Abbar, H., \& Shaheed, H.H. (2021). The difference between American sign language and body language in greetings Najlaa. Multicultural Education, 7(5), 174-181.

Ambrozy, M., Pavlikova, M., \& Kobylarek, A. (2021). How to teach philosophy during Covid 19? EDULEARN21 Proceedings (pp. 7451-7456). Palma: IATED. https://doi.org/10.21125/edulearn.2021.1510

Banks, J.A. (2001a). Cultural diversity and education: Foundations, curriculum and teaching. 4th ed. Boston: Allyn and Bacon.

Banks, J.A. (2001b). Multicultural education: Its effects on students' racial and gender role attitudes. In J.A. Banks \& Ch.A. McGee Banks (Eds.), Handbook of Research on Multicultural Education. San Francisco: Jossey-Bass.

Banks, J.A. (2013). The construction and historical development of multicultural education, 1962-2012. Theory into Practice, 52(1), 73-82.

Bartkova, G. (2015). Multikultúrna výchova na školách. Prešov: UPJS. (In Slovak.)

Belinskaya, E.P. (2018). Modern identity research: From structural certainty to procedurality and incompleteness. Bulletin of Saint Petersburg University. Psychology, 8(1), 6-15. (In Russ.) http://dx.doi.org/10.21638/11701/spbu16.2018.101

Binetti, M.J., Novakova, K.S., \& Pavlikova, M. (2019). ¿Multiculturalismo o feminismo? La discusión en torno al uso del velo integral. XLinguae, 12(1), 70-79. http://dx.doi.org/10.18355/XL.2019.12.01.05

Bogdanova, O.A. (2016). The crisis of self-identity in postmodern culture. Scientific Thought of Caucasus, (2), 26-31. (In Russ.)

Durkova, E. (2020). Changes in belief in personal God among youth in Slovakia. Religiosity, Spirituality and Alternative Religious Movement. Nitra: UKF.

Faltyn, J. (2005). Teoretická východiska multikuturní andragogiky. Praha: MJF. (In Czech.)

Garmon, M.A. (2004). Changing preservice teachers' attitudes/beliefs about diversity: What are the critical factors? Journal of Teacher Education, 55(3), 201-213.

Gay, G. (2000). Culturally responsive teaching: Theory, research and practice. New York: Teachers College Press. 
Gorski, P. (2006). Complicity with conservatism: The do politicizing of multicultural and intercultural education. Intercultural Education, 17(2), 163-177.

Gorski, P. (2009). What we're teaching teachers: An analysis of multicultural teacher education coursework syllabi. Teaching and Teacher Education, 25(1), 309-318.

Grant, C., \& Sleeter, C. (2006). Turning on learning: Five approaches to multicultural teaching plans for race, class, gender, and disability. Upper Saddle River, NJ: Prentice Hall.

Halah, A.A. (2016). Multicultural education: Teachers' perceptions and preparation. Journal of Education and Practice, 7(11), 139-146.

Hašková, A., Šafranko, C., Pavlíková, M., \& Petrikovičová, L. (2020). Application of online teaching tools and aids during corona pandemics. Ad Alta: Journal of Interdisciplinary Research, 10(2), 106-112.

Kalustyants, J.S. (2011). Personality in conditions of identity crisis: Social transformation and individuation. Bulletin of the North Caucasus State Technical University, 27(2), 162-166. (In Russ.)

Karatsova, V.N., \& Isaev, E.A. (2016). Organizational and methodical bases of multicultural self-organization of students in the additional foreign language education. RUDN Journal of Psychology and Pedagogics, (2), 99-109. (In Russ.)

Khukhlaev, O.E., Gritsenko, V.V., Pavlova, O.S., Tkachenko, N.V., Usubian, S.A., \& Shorokhova, V.A. (2020). Comprehensive model of intercultural competence: Theoretical substantiation. RUDN Journal of Psychology and Pedagogics, 17(1), 13-28. http://dx.doi.org/10.22363/2313-1683-2020-17-1-13-28

Kondrla, P., Tkáčová, H., \& Tvrdoň, M. (2020). Social work and its impact on alleviating the social exclusion of religious minorities. ICERI2020 Proceedings (pp. 3844-3851). Seville: IATED. https://doi.org/10.21125/iceri.2020.0872

Kondrla, P., Tvrdoň, M., \& Tkáčová, H. (2020). Current challenges for social work: stereotyping as an obstacle to the integration of marginalized groups into society. ICERI2020 Proceedings (pp. 3837-3843). Seville: IATED. https://doi.org/10.21125/iceri.2020.0870

Králik, R., \& Máhrik, T. (2019a). Interpersonal relationships as the basis of student moral formation. ICERI2019 Proceedings (pp. 8896-8900). Seville: IATED. https://doi.org/10.21125/iceri.2019.2129

Králik, R., \& Mahrik, T. (2019b). Metaphysics as a base for improving critical thinking. ICERI2019 Proceedings (pp. 8901-8903). Seville: IATED. https://doi.org/10.21125/iceri.2019.2130

Kroupova, A. (2008). Tolerance a mediální gramotnost v multikulturním prostředí: Sylaby a anotace vybraných př̀spěvků. Praha: UK. (In Czech.)

Kyselova, J., \& Ligas, S. (2017). Multikultúrna výchova žiakov v predmete etická výchova. Banska Bystrica, UMB. (In Slovak.)

Kyuchukov, H., \& New, W. (2018). Mother tongue of Roma children from special schools. RUDN Journal of Psychology and Pedagogics, 15(3), 323-333. http://dx.doi.org/10.22363/23131683-2018-15-3-323-333

Mistrík, E. (2011). Ciele a obsah multikultúrnej výchovy a vzdelávania pre Štátny vzdelávací program ISCED 0 a ISCED 1. Bratislava: Štátny pedagogický ústav. (In Slovak.)

Mistrík, E., et al. (2008). Multikultúrna výchova v škole. Bratislava: NOS. (In Slovak.)

Mosanya, M., \& Kwiatkowska, A. (2021). Complex but integrated: Exploring social and cultural identities of women Third Culture Kids (TCK) and factors predicting life satisfaction. International Journal of Intercultural Relations, 84, 65-78. https://doi.org/10.1016/j.ijintrel.2021.07.001

Pavlíková, M., \& Žalec, B. (2019). Struggle for the human self and authenticity: Kierkegaard's critique of the public, established order, media, and false christianity. Bogoslovni Vestnik/ Theological Quarterly, 79(4), 1015-1026. https://doi.org/10.34291/BV2019/04/Pavlikova

Pavlikova, M., Tkáčová, H., Kobylarek, A., \& Biryukova, Y. (2021). Factors arousing academic interest of high school students in studying at university. EDULEARN21 Proceedings (pp. 7814-7823). Palma: IATED. https://doi.org/10.21125/edulearn.2021.1594 
Petrovič, F., \& Murgaš, F. (2020). Linking sustainability and happiness. What kind of happiness? GeoScape, 14(1), 70-79. https://doi.org/10.2478/geosc-2020-0007

Sandorova, V. (2011). Multikultúrna výchova na I. stupni ZŠ. Bratislava: Metodicko - pedagogické centrum. (In Slovak.)

Siskova, T. (2008). Výchova k toleranci a proti rasismu: multikulturni výchova v praxi. Praha: Portal. (In Czech.)

Tkáčová, H., Al-Absiová, E., Al-Absi, M., \& Pavlíková, M. (2021). "Media Invasion” against Islam in the context of the Slovak Republic. Media Literacy and Academic Research, 4(1), 165-179.

Tkáčová, H., Pavlíková, M., Tvrdoň, M., \& Jenisová, Z. (2021). The use of media in the field of individual responsibility for sustainable development in schools: A proposal for an approach to learning about sustainable development. Sustainability, 13, 4138. https://doi.org/10.3390/su13084138

Tkáčová, H., Pavlíková, M., Tvrdoň, M., \& Prokopyev, A. (2021). Existence and prevention of social exclusion of religious university students due to stereotyping. Bogoslovni Vestnik/Theological Quarterly, 81(1), 199-223. https://doi.org/10.34291/bv2021/01/tkacova

Tkáčová, H., Tvrdoň, M., Králik, R., \& Kalugina, A. (2021). End of the procrastination through innovation in education. Factors maintaining motivation in study among university students. EDULEARN21 Proceedings (pp. 6838-6847). Palma: IATED. https://doi.org/10.21125/edulearn.2021.1384

Tkáčová, H., Tvrdoň, M., Roubalova, M., \& Vasbieva, G. (2021). Factors of academic interest of social workers and social work assistants in lifelong learning: Are online forms of education (de) motivating? EDULEARN21 Proceedings (pp. 6823-6831). Palma: IATED. https://doi.org/10.21125/edulearn.2021.1381

Ukpokodu, O.N. (2003). Teaching multicultural education from a critical perspective: Challenges and dilemmas. Multicultural Perspectives, 5(4), 17-23.

Zalec B., \& Pavlikova, M. (2019). Religious tolerance and intolerance. European Journal of Science and Theology, 15(5), 39-48.

Žalec, B., \& Pavlíková, M. (2019). Civic virtues and functions of religion in public life. European Journal of Science and Theology, 15(6), 75-84.

Slavin, R.E., Hurley, E.A., \& Chamberlain, A.M. (2001). Cooperative learning in schools. In N.J. Smelser \& B. Baltes (Eds.), International Encyclopedia of the Social and Behavioral Sciences (pp. 2756-2761). Oxford, England: Pergamon.

\section{Article history:}

Received 25 June 2021

Revised 8 August 2021

Accepted 10 August 2021

\section{For citation:}

Kondrla, P. (2021). Multicultural education in Slovakia: Perspectives and risks. RUDN Journal of Psychology and Pedagogics, 18(3), 507-519. http://dx.doi.org/10.22363/23131683-2021-18-3-507-519

\section{Bio note:}

Peter Kondrla, $\mathrm{PhD}$, Associate Professor, is a teacher at the Department of Religious Studies, University of Constantine the Philosopher in Nitra. His scientific focus and research subjects are philosophy of values, history of Christian philosophy, postmodern philosophy, philosophy of religion, didactics of religious education, philosophy of religion, values of life and biblical studies. ORCID: https://orcid.org/0000-0003-4857-5578 E-mail: pkondrla@ukf.sk 


\title{
Мультикультурное образование в Словакии: перспективы и риски
}

\author{
П. Кондрла \\ Университет Константина Философа в Нитре, \\ Словацкая Республика, 949 74, Нитра, ул. Ходзова, д. 1 \\ $\square$ pkondrla@ukf.sk
}

\begin{abstract}
Аннотация. Анализируется 20-летний опыт мультикультурного образования в Словакии. Отправной точкой является изучение побудительных мотивов и причин включения мультикультурного образования в систему образования. Внедрение мультикультурного образования обосновывается в контексте текущих возможностей и потребностей общества; выявляются актуальные проблемы, которые мультикультурное образование решает сегодня. Представлены основные принципы и базисные элементы мультикультурного образования, исследуются их сильные и слабые стороны. Акцент делается на принципах уважения человеческого достоинства и социальной ответственности как источниках, на которых базируются другие ценности мультикультурного образования. Показано, что в реальной жизни среда, в которой происходит обучение, зачастую противоречит этим принципам. Школьная и семейная среды не обеспечивают достаточной подготовки, не формируют приоритетов и часто не уважают ценности мультикультурализма. Возникающий в результате конфликт между принципами и средой представляет собой самую большую проблему и риск в мультикультурном образовании в Словакии. Особое внимание уделяется вопросу образования на родном языке, эта проблема в Словакии главным образом затрагивает цыганское меньшинство. Невозможность для цыган учиться на родном языке противоречит декларациям о равных правах и возможностях для развития всех людей без ущемления их человеческого достоинства. Поиск перспектив для развития мультикультурного образования в Словакии требует изменений как в школьной среде, так и в ценностных ориентациях и личном отношении отдельных учителей, а также и изменений в их подготовке к будущей профессии.
\end{abstract}

Ключевые слова: мультикультурное образование, мультикультурализм, толерантность, Словакия, родной язык, меньшинство, культурное разнообразие

\section{История статьи:}

Поступила в редакцию 25 июня 2021 г.

Принята к печати 10 августа 2021 г.

\section{Для цитирования:}

Kondrla P. Multicultural education in Slovakia: perspectives and risks // Вестник Российского университета дружбы народов. Серия: Психология и педагогика. 2021. T. 18. № 3. C. 507-519. http://dx.doi.org/10.22363/2313-1683-2021-18-3-507-519

\section{Сведения об авторе:}

Кондрла Петер, $\mathrm{PhD}$, доцент, преподаватель кафедры религиоведения, Университет Константина Философа в Нитре. Его научные интересы включают философию ценностей, историю христианской философии, философию постмодерна, философию религии, дидактику религиозного образования, философию религии, жизненные ценности и библейские исследования. ORCID: https:/orcid.org/0000-0003-48575578 E-mail: pkondrla@ukf.sk 